\title{
1. Entrepreneurship in action: the power of the student-run venture
}

\section{Mark Tonelli}

Investing in a decade's worth of education takes commitment. This commitment, in my experience at least, stems from inspiration. In the 1980s, as a teenager, I looked up to my high school choir teacher. He had a knack for connecting with students and shared about his efforts to complete his doctorate in piano performance while teaching. I wanted to follow in his footsteps, and this inspired me to pursue a doctorate. It's safe to say that I didn't know what I was in for.

Every doctoral student faces the same challenging question - "What should my dissertation be about?" It's a question I asked myself frequently, even before beginning my doctorate journey. I imagined choosing a topic tied to music performance or music education. But the world started to change, and my interests and what I saw as necessary shifted. As I began my doctoral work, I realized that people communicated, shopped, relaxed, ate, and essentially lived differently. Why? Because of technology.

Technology, particularly the internet, had changed everything. In turn, that change caused a shift in the way people work. The traditional model of graduating from college and working loyally for the same company for the next 30 years was beginning to vanish. In its place, fueled by technology, economic volatility, and globalization, the concept of being an entrepreneur began to emerge. College students needed to learn skills for their respective fields, know how to create their own work, identify opportunities in rapidly shifting markets, and discover how to be resilient, adaptable, and flexible. In other words, this edition of college students needed to reinvent themselves, like how the world of the 21 st century reinvented itself.

This trend was just one of many I was trying to decode. I also came to realize that while I received the best musical training you could buy, I did not receive training on how to translate those hard-earned musical skills into a sustainable career. There were no courses on music entrepreneurship or a "do-it-yourself" music career. I had been guided towards my passion but not necessarily given instruction on how to forge a sustainable career path. 
The "business" aspects of a music career were not on anyone's radar at this time. We were primarily concerned with being the best musicians - convinced somehow that our superior musical skills would "get us noticed" and lead to financial success. You know, it was that old chestnut of being in the right place at the right time, and believing that if you worked hard enough on your craft, you would succeed.

Once I completed graduate school in 2000 and began my professional career, I waited for the job offers to start pouring in. They came but only in spurts and not as steadily as I had imagined. It was not long before I realized that if I wanted to have a career as an artist, I would have to create that career myself. This began my on-the-job education of learning to create opportunities for myself.

I was not alone. I soon discovered that friends and colleagues in the industry were having similar struggles, and together we cried, "We were not prepared for this!" After ten years in the trenches, I began to see a need for reform in music education. Students needed to prepare for their new reality. They will have to create their own careers; they will have to become entrepreneurs as well as artists.

These observations culminated in a worthy topic for my dissertation. I would study how entrepreneurship was taught in college music programs, and to what level it impacted the potential of a musician. It wasn't a topic I had ever considered before coming to the revelation that some of the most talented musicians did not know how to create opportunities to showcase their talent. This meant that all the musical training in the world would not matter to them without instruction on how to turn that skill and passion into a sustainable career or business.

My research concluded that integrating entrepreneurship in college music programs is valuable and makes a positive difference in the careers of students. This is not an abstract concept. It applies directly to my own career. Even though I now teach full-time, I continue to be entrepreneurial. I create opportunities for my ensemble to perform, publish music instructional books, write a blog, present at conferences, post on social media, record new music, and constantly network. If I ever stopped doing these things, my career would stagnate, and I, as a music performance and entrepreneurship professor, would no longer be relevant. After all, professors and institutions must innovate along with the rest of the world to fulfill the needs of their students.

A few years ago, I arrived at Millikin University as an entrepreneurial musician. Millikin University, an institution that breathes entrepreneurship, was founded in 1901 as a small, private institution located south of Chicago in Decatur, Illinois. The school is small with enrollment of around 2,000 undergraduate and 90 graduate students. The university is known for its arts, nursing, and business programs, including entrepreneurship. 
At the time, Millikin's entrepreneurial engine was primarily fueled by the Center for Entrepreneurship (CFE), led by Director Julie Shields and Coordinator Kate Flemming, who both have made significant contributions to the entrepreneurial success at Millikin and this book. I felt an instant connection to the CFE and agreed to serve on a planning committee for the national conference of the Society for Arts Entrepreneurship Education (SAEE). It was during the SAEE conference, hosted at Millikin, that I began to discover a new world - the student-run venture. I attended a panel organized by Sara Theis, who teaches Pipe Dreams Studio Theatre, a student-run venture in which students run a black box theatre. The panel was composed of current and former students who discussed the profound impact Pipe Dreams had or was having on their careers and development. After the conference, the planning committee reviewed surveys completed by attendees. The Pipe Dreams panel session and the student-run venture concept was mentioned over and over as a highlight for attendees. It was clear that something special was happening at Millikin with our student-run ventures.

\section{WHAT IS A STUDENT-RUN VENTURE (SRV)?}

A student-run venture allows students to earn college credit for learning how to run a business by running a business. They get hands-on experience by taking over the operations of a fully functioning business. As discussed in Chapter 13, I eventually created my own student-run venture, Arts Café, and have become part of the community of student-run ventures at Millikin.

Through my fellowship with the Coleman Foundation, which supports entrepreneurship education in academia, I have also had the opportunity to meet and work with Coleman Fellows on Millikin's campus, and learn about their student-run ventures. Creating a network of educators all focused on enhancing entrepreneurship education through student-run ventures has helped us guide stronger student-run ventures on our campus while allowing us to share our successes and failures to help others.

Millikin currently has 15 student-run ventures, nearly double the number of ventures as when I arrived in 2016. As I observe the work of my colleagues who teach other student-run ventures, I am impressed by the scope and relevance of what they are doing. Collectively, our students acquire critical skills and accelerate their learning in a way that is not possible without student-run ventures. Through experiential learning in a real business on campus, students get relevant and valuable experience in a low-risk environment while earning college credit.

As I considered the breadth and quality of my colleagues' work, the impact it was having on our students' development and success, and the interest that entrepreneurship educators had with our student-run ventures at the SAEE 
conference, it occurred to me that our work could be valuable to a wider audience. Why should this model and these approaches stay within the walls of Millikin University when millions of students around the world could benefit greatly from student-run ventures?

Entrepreneurship in Action: The Power of the Student-Run Venture should be utilized as a guide to draw from similar, yet vastly different approaches to teaching students how to develop entrepreneurship skills. Millikin's work has broad application across multiple academic disciplines, and we are excited to make this information available to impact your teaching, institution, and most importantly, your students.

Each case in this book discusses one of six different student-run ventures at Millikin University, with each being led by a different professor with their own unique approach. Emerging from their pedagogy are themes that exemplify the work they are doing.

Meet your other student-run venture guides:

\section{Dave Burdick, Art Circus, a Performance Art Group}

- Opportunity recognition

- Impact feasibility

- Vision

\section{Kate Flemming, Blue Connection, an Art Gallery}

- Creative entrepreneurial collisions

- "Drinking from a firehose" structure

- Customer-gallery-artist triangle

- Exploring new organizational tools

\section{Sara Theis, Pipe Dreams Studio Theatre, a Black Box Theatre}

- Listening

- Pivoting

- Intervention

\section{RJ Podeschi, MU Performance Consulting, an IT Business}

- How technology-based SRVs are different from traditional business model SRVs

- Strategies for sustainability in SRVs, knowledge transfer

- Balance between hands-on and hands-off as a faculty advisor/leader of a SRV 


\section{Mark Tonelli, Arts Café, a Live Performance Venue}

- Selling an experience

- Consistently delivering a high-quality product

- Developing leadership abilities in students

Just as our students learn lessons from each of our student-run ventures that they can apply to future careers and businesses, you will find information, approaches, and new tools that you can apply to your unique instructional context, whether it is in the arts or business, secondary or post-secondary education. You will find both highly individualized approaches to teaching SRVs as well as recurrent themes that surface across chapters. The principles embodied in these themes can be transferred and employed by teachers across multiple disciplines with students in a variety of situations in macro and nuanced scenarios. Put simply, this book has a lot to offer you, regardless of your program's current makeup.

Are you new to SRVs? If you have never taught a student-run venture, then you will find a wealth of enlightenment for starting one using our 50+ years of combined experience teaching student-run ventures. As I learned in my time at Millikin, starting and teaching a student-run venture is not as challenging as you might think, and incredibly rewarding for you, the school community, and your students. We have packed this book full of everything you need to learn about SRVs, compare approaches, and gain new ideas that will help you take away what works for you. Whether you decide to launch an SRV at your institution or just dip your toes into the entrepreneurship instruction pool outside of post-secondary education - come on in, the water's fine, and there are lifeguards standing by to help!

Don't just take our word for it. You will also read about the experiences of Millikin graduates who were formerly enrolled in student-run ventures. They tell it in their own words, providing the big picture of how student-run ventures can have a positive impact on graduates' careers. Their experiences, combined with the knowledge of our instructors, make this book a valuable resource. I hope it will be a source of tools, strategies, and inspiration for you and your future as an entrepreneurship educator. 